\title{
International Community Service Program Model for Teacher Prospective Students at Universitas Muhammadiyah Enrekang
}

\author{
Mustakim ${ }^{1}$, Sukree Doloh², Yunus Busa ${ }^{3}$ \\ ${ }^{1}$ English Education Department, Universitas Muhammadiyah Enrekang, Indonesia \\ ${ }^{2}$ Nirandonwitya School, Narathiwat, Thailand \\ ${ }^{3}$ Non-Formal Education Department, Universitas Muhammadiyah Enrekang, Indonesia \\ Email: kimchangi00@gmail.com ${ }^{1}$; sanree232127@gmail.com ${ }^{2}$; yunus busa@yahoo.com ${ }^{3}$
}

\section{ARTICLE INFO \\ Article History: \\ Received February 202 \\ Accepted 11 February 2020}

Keywords:

International Community Service Program, Teacher Prospective, Internationalization of Higher Education, Implementation.

\section{ABSTRACT}

The research aimed to describe the implementation of the International Community Service Program which has been done at STKIP Muhammadiyah Enrekang. Specifically the research seeked to uncover: (1) The implementation of International Community Service Program which has been carried out so far; (2) The effectiveness of implementation International Community Service Program was seen from the responses of the stake holders and participants; and, (3) International Community Service Program model formulation for prospective teachers in STKIP Muhammadiyah Enrekang. For achieving these objectives, exploratory studies were carried out with an approach descriptive qualitative. The research involved STKIP Muhammadiyah Enrekang where stakeholders were the main respondents. Information in the field was explored using interview, analysis techniques documents, and questionnaire distribution. After the data was collected and processed. The research concludes as follows: (1) International Community Service Program is a program which important, therefore; even really needs to be done; and (2) International Community Service Program for prospective teachers in STKIP Muhammadiyah Enrekang based on the needs analysis in the field has unique characteristics of aspects: (a) duration of implementation: (b) destination country; (c) the amount of the fee needed; (d) the frequency of monitoring needed; (e) participants who involved; (f) parties involved, (f) activity management team, and (g) material required activities. Research recommends things following: (1) analyzing field requirements before the International Community Service Program implemented, (2) doing careful preparation, (c) doing reflection at each stage of implementation. 


\section{INTRODUCTION}

The implementation of the Community Service Program is designed to prepare students to reach three main targets as expressed by Perdana, Holilulloh, and Nurmalisa (2013). First, Community Service Program is expected to be a learning tool for students (Community Service Program participants) to apply various theories they obtain during their studies, according to their respective scientific disciplines. Second, Community Service Program can provide positive values in order to improve the quality of people's lives. Third, Community Service Program is a media to build partnerships between the relevant tertiary institutions and the community, including as an effort to build an image and can be used as a promotional site for the relevant tertiary institution. Even in this case, the government established Government Regulation Number 19 of 2005 concerning National Education Standards specifically related to CHAPTER V Article 26 Paragraph 4, which essentially contains the formulation of competency standards for university graduates. This legal effort aims to: "prepare students to become members of a society of noble character, possessing knowledge, skills and independence, as well as attitudes to apply science, technology, and art for humanitarian purposes (Astute et at., 2013: 4).

The Community Service Program, including the International Community Service Program, has been institutionalized in higher education institutions. A number of studies have been carried out to uncover its effects. For example, Hanks \& Grayman (2009) who examined the impact of International Community Service on the perception of personality changes. Then,
Niehaus \& Crain (2013) who examined the impact of the International Community Service on one's view of the world. Likewise, Pless, Maak, and Stahl (2011) who examined the impact of the International Community Service Program on leadership competence. Furthermore, research has also led to efforts to develop a conceptual model of the International Community Service Program, as conducted by Kiely (2005) and Pechak, and Thompson (2009). However, none of the researchers discussed the International Community Service Program at the STKIP Muhammadiyah Enrekang.

The type of community service program then developed into an International (Integrated) Community Service Program. This International Integrated Community Service Program is an implementation of Community Service Program in combination with internship program in the destination country (Ismail, Hasan, \& Musdalifah, 2019). Just as is being done by STKIP Muhammadiyah Enrekang. The Integration of International Community Service Program - Internship Program is held by STKIP Muhammadiyah Enrekang once in a year, which began in 2018 until now. The implementation is in Thailand, precisely in the Pattani, Narathiwat, Songkla, Yala and Phuket regions. Integrated International Community Service Program- Internship Program is a lecture and field work activity which is an integration of education and teaching, research and community service by students in a pragmatic manner, with a broad dimension through an interdisciplinary, comprehensive and crosssectoral approach. The integration of International Community Service Program Internship Program activities is in the form 
of integration of management and time aspects (Astuti, 2012). The aim of community service program-internship program is to develop student competencies as professional teacher candidates, giving students experience in the field learning and managerial in schools / madrassas in order to train and develop teacher competencies and expertise according to their fields, as well as improve students' ability to apply knowledge and skills that have been mastered into real life at school or outside the school in accordance with scientific background.

The stages of implementation of the International Community Service Program can be clearly described in the table below.

Table 1. The stages of implementation of the International Community Service Program

\begin{tabular}{llll}
\hline Burn (1998) & $\begin{array}{l}\text { Berastagi, } \\
\text { Alonso, \& Roman } \\
(\mathbf{2 0 1 6 )}\end{array}$ & $\begin{array}{l}\text { M. Pechak \& Thompson } \\
\mathbf{( 2 0 0 9 )}\end{array}$ & $\begin{array}{l}\text { Baker - Boosamra } \\
\mathbf{( 2 0 0 6 )}\end{array}$ \\
\hline Preparation & Diagnosis & Development & Preparation \\
\hline Accomplishment & Gathering information & Design & Action \\
\hline Final assessment & Design & Implementation & Reflection \\
\hline & Implementation & Evaluation & Reioprocity \\
\hline & & Enhancement & \\
\hline
\end{tabular}

In carrying out activities there are always challenges and obstacles, especially with the International Community Service Program which is implemented in foreign countries with different cultural, demographic, and sociological contexts. As with internships and other social service activities, International Community Service Program has many challenges. Even the challenges are greater than domestic Community Service Program. Sandy \& Holland (2006) said there are five challenges for implementing International Community Service Program: (1) the lack of information or resources for integrating service-learning with existing courses; (2) arrange new courses; (3) rejection of services provided, (4) logistical difficulties for placement in the community; (5) lack of time for communication, collaboration and planning, and (6) limited funds for programming. Tryon (2008) formulated 5 challenges in the implementation of the International Service Learning (ISL) (including International Community Service Program) for the implementation team. (1) staff time; (2) the ability of staff to conduct training and supervision; (3) incompatibility with direct services to parties served; 4) project time and management, (5) and academic calendar issues. Furthermore, George \& Shams (2007) one major challenge in the implementation of the International Community Service Program, namely: the criteria for successful implementation of activities. By using a customer satisfaction measure as the basis for successful implementation, it is recommended that the assessment include various aspects such as: technical success, sustainability of project activities, and wider impact.

\section{Methods}


This research was designed with the "Research and Development" approach. One of the characteristics of this research design is the existence of a standardized product or model to use. The main objective of this research was to find or create an International Community Service
Program model development product for prospective teacher students in the STKIP Muhammadiyah Enrekang environment that is needed by users and stakeholders.

The research step follows the modified research and development stages of Borg \& Gall (1976: 626). In general, these steps are described in the table below.

Table 2. The research step follows the modified research and development stages of Borg \& Gall

\begin{tabular}{ll}
\hline Exploratory Study & At this exploratory stage, researchers looked for International Community \\
& Service Learning models which were found in several universities that have \\
already carried out International Community Service Program to ASEAN \\
countries. Empirical (practical) model discovery in the field provided information \\
regarding: (a) the conditions of the implementation of the International \\
Community Service Program implemented in several universities; (b) education \\
and training system in tertiary institutions; (c) curriculum, (d) development \\
needs, (e) potential, and (f) problems encountered. \\
\hline Verification Model & $\begin{array}{l}\text { (1) Conduct conceptual validation of experts, (2) Conduct validity of models to } \\
\text { practitioners, (3) Conduct limited trials, regarding the applicability of } \\
\text { representative models to be implemented, (4) Perform predictive and systemic } \\
\text { analysis of results limited trials, (5) conducting triangulation. }\end{array}$ \\
\hline Implementation & $\begin{array}{l}\text { In applying this model both the policy makers / leaders, supervisors and experts } \\
\text { in the field of International Community Service Program join as a team to }\end{array}$ \\
implement a model that has been considered valid. The activities carried out \\
refer to the focus of model development, including; analysis and preparation of \\
an international service program model framework, management of developing \\
international service program models and strategies, methods of \\
implementation, and evaluation patterns and development of international \\
service program models.
\end{tabular}

Research subjects at the exploration stage were stakeholders in STKIP
Muhammadiyah Enrekang who had and are still carrying out International Community 
Service Program. While the data collection techniques, which will be obtained from the STKIP Muhammadiyah Enrekang which implement the International Community Service Program, in this research and development are; (a) participatory observation, (b) interview, (c) questionnaire, and (d) documentation study.

\section{RESULT AND DISCUSSION}

\subsection{International Community Service Program for Prospective Teachers at STKIP Muhammadiyah Enrekang.}

According to data obtained through questionnaires and interviews, International Community Service Program implementation by STKIP Muhammadiyah Enrekang in this study are divided into three major steps that are interrelated with each other, including steps before implementation, steps during implementation, and steps after implementation. Each step is enriched by various relevant activities for the realization of the International Community Service Program. The following are the steps for implementing an international service learning program based on interviews with stakeholders.

\subsubsection{Pre-Implementation of the International Community Service Program}

In the process of gathering information related to activities that are conducted by STKIP Muhammadiyah Enrekang before conducting the International Community Service Program, Questionnaire and Transcript of interviews marked or thematically coded according to the categories that have been prepared, including the Pre, Whilst, and Post categories. Based on the categorization of data contained in the Interview Questionnaire and Transcript, several activities were collected which were included in the Pre-Implementation of the International Community Service Program: a) Correspondence; b) Survey or Preliminary Study; c) Signing of the MoU; d) Recruitment of International Community Service Program Participants; e) International Community Service Program Participant Selection Tests; f) Passport Issuance; g) Debriefing; h) Determination of Field Supervisor Lecturers; and i) Delivery to the Destination Country.

\subsubsection{Implementation of International Community Service Program}

The implementation of the International Community Service Program begins with the handover of the Community Service Program participants from the university to the schools in the destination country. The implementation continued with the application of several activity cycles which altogether adopted participatory action research (PAR).

\subsubsection{Handover of International KKN Participants}

The handover is a continuation of the International Community Service Program participants' departure to Thailand. After arriving at their destination, the International Community Service Program participants, field supervisors, and chairperson of STKIP Muhammadiyah Enrekang or International Affairs Office prepare to attend the handover at the predetermined place and time. 
One thing is the same in the procession of the handover of International Community Service Program namely the involvement of the most important people from the surrender (university) and the recipient (destination country). From parties universities, Chancellors or officials assigned to submit International Community Service Program participants received by the respected ones from the Pattani Region Islamic Religion Council, Alumni Association to the Director of the First and Middle Educational Institutions, the Indonesian Consulate in Songkhla, and the Muslim School Association in Southern Thailand. In fact, when the handover procession, the recipient, namely all levels of government from the Regent to a public figure, welcomed the arrival of the university to implement the International Community Service Program in their country.

This handover procession takes place every year for the university parties to continue send ing participants in the International Community Service Program. The excitement of the handover at the beginning is as lively as the release of the International Community Service participants at the end of the event. This is recognized by the stakeholders and all participants of the International Community Service Program.

The Community Service Program in Thailand is carried out by STKIP Muhammadiyah Enrekang for a long period of time, which is approximately 5 months. During this time, there are several stages that have to be passed by International Community Service Program participants, which are then packaged through the following activity cycles.

\section{Cycle 1}

The first stage in the implementation of the International Community Service Program after its existence. The participants are officially welcomed by the destination country, namely to make friendship to the teacher's room, staff and class (field). The purpose of this friendship is, as expressed by the respondent participants as follows: 1. Establishing a good sense of family with the teachers, staff, students and of course the school director. 2. Seeing the class situation to be taught. 3. Getting classes and class schedules and the number of hours to be taught in a week.

\section{Cycle 2}

This cycle is a cycle where international participants are required to teach in class according to their respective study programs. Each participant must teach according to the schedule given. The participants also performed various activities such as providing Qur'an writing and reading training before entering class or after the evening prayer. Participate in school scout activities both within the school environment and outside the school. Sometimes the scouting activity is attended by several schools around the area. In addition, participants, especially men, will give sermons on Friday.

\subsubsection{Post-Implementation of International Community Service Program}

The activity carried out by the respondents involved in this research when the International Community Service Program is carried out is to make a report. Who needs to make a report? All field supervisors and students participating in 
the International Community Service Program. The main task of the field assistant lecturer is to accompany the activities of students during a visit. Field assistant lecturers generally make 2 visits, namely at the beginning when the handover of students participating in the International Community Service Program, and at the end when returning from Thailand. Thus, for each visit, the field assistant lecturer is required to make a report on the results of the field assistance every time he visits by filling out the form provided by research and community service institutions.

The contents of the first visit report are generally related to location International Community Service Program, student admission director, school circumstances, programs that will be run by students, and at the same time discuss work plans to identify problems and potentials at the International Community Service Program. While the contents of the last week's visit report are reporting on activities that have been carried out by International Community Service Program participants, testimonies of school directors, teachers, staff and students on International Community Service Program activities, releasing Community Service Program participants from directors and schools, and reporting input suggestions and criticisms from schools.

While the reports that must be made by students participating in the International Community Service Program on the implementation of their performance include weekly reports, final reports, and presentation reports. For monitoring International Community Service in Thailand, each group is required to make weekly reports (first, second week and so on). Weekly reports take the form of quoting the term used by White (2001) which is 'field notes', the results of program planning and implementation International Community Service and other working papers. This final International Community Service Program report is prepared by each participant at their school. This final report consists of three forms, namely an academic report, an executive summary report, and a documentary film or Photo Flash.

\section{CONCLUSION}

The study raised three main issues as formulated in the objectives of this study: (1) describing the International Community Service Program carried out so far; (2) illustrates the effectiveness of the implementation of the International Community Service Program in terms of stakeholder and user responses; and, (3) formulation of the International Community Service Program model for prospective teachers at STKIP Muhammadiyah Enrekang. The following conclusions are presented after the data has been processed and analyzed.

First, the International Community Service Program held so far in Southeast Asia countries is the main destination country, namely Thailand, specifically three southern Thai provinces, such as Pattani, Narawita and Yala. The main consideration in choosing the three provinces is because of the closeness of culture, religion, and the existence of Islamic schools in the country to become facilitators in the program. Secondly, the International Community Service Program is an important program, by therefore; it really needs to be done. Indicators that this program needs to be 
seen include: (a) Trying various ways for this program to continue. (b) Making cooperation documents (MoU), and (c) Official budgeting for International Internship Activities. Considering this fact, it is seen to formulate an effective international internship model for prospective teacher students at STKIP Muhammadiyah Enrekang. Third, the International Community Service Program model for prospective teachers in STKIP Muhammadiyah Enrekang which based on field needs analysis has unique characteristics: (a) lasts 1-5 months, (b) ASEAN countries as the main destination countries; (2) the amount of the cost of 6-7 million which is partly subsidized by the organizer of the university, (c) the frequency of monitoring once during the activity, excluding closure and opening, (d) participants who vary from various majors / study programs, with priority on prospective teacher students, (e) involvement of various parties, (f) adequate preparations managed by special teams, and (g) material activities that empower and get a monthly salary during the program. The study recommends that International Community Service Program be better managed by doing the following things: (a) analyzing the field needs to formulate clear goals / targets, (b) doing careful preparation, (c) conducting evaluations or reflections during preactivity, main activities, and postCommunity Service Program activities.

\section{References:}

1) Arikunto, Suharsimi. (1993). Kesiapan Lulusan Sekolah Pendidikan Guru dalam mengajarkan Matematika dan
IPA di SD, Disertasi, Jakarta: Program Pascasarjana IKIP Jakarta.

2) Astuti, N.W.W., Suhandana, I.G.A. dan Dantes, N. (2012). Evaluasi efektivitas pelaksanaan Praktik Pengalaman Lapangan (PPL) mahasiswa.

3) Baker-Boosamra, M. (2006). SPNA Review From Service to Solidarity: Evaluation and Recommendations for International Service Learning. Retrieved from http://scholarworks.gvsu.edu

4) Batool, Z., Ellahi, N., and Masood, A. (2012). National internship programme and its evaluation: A case study of Punjab region. Academic Research International, 2(2), 256-570.

5) Berasategi, N., Alonso, I., \& Roman, G. (2016). Service-learning and Higher Education: Evaluating Students Learning Process form their Own Perspective. Procedia - Social and Behavioral Sciences, 228, 424-429. https://doi.org/10.1016/i.sbspro.2016. $\underline{07.065}$

6) Borg, W.R and Gall, M.D. (1979). Educational Research An Introduction. New York : Longman. 89

7) Brook dan Emmert. (1989). The Psychology of Adolescence. Third Edition. New Jersey: MacMilland Publishing. Co. Inc.

8) Gaines-Hanks, N., \& Grayman, N. (2009). International service-learning in South Africa and personal change: An exploratory analysis. NASPA Journal, 46(1), 72-93. doi: 10.2202/19496605.5006.

9) George, C., \& Shams, A. (2007). The challenge of including customer satisfaction into the assessment criteria of overseas service learning projects. 
International journal for service learning in engineering, 2(2), 64-75.

10) Ismail, I., Hasan, H., \& Musdalifah, M. (2018). Pengembangan Kompetensi Mahasiswa Melalui Efektivitas Program Magang Kependidikan. Edumaspul: Jurnal Pendidikan, 2(1), 124-132. https://doi.org/10.33487/edumaspul.v $2 \mathrm{i} 1.48$

11) Kiely, R. (2005a). A transformative learning model for service-learning: $A$ longitudinal case study. Michigan Journal of Community Service Learning, 12(1), 5-22.

12) Mustakim, Salman. (2019). Character Building Based on Local Culture (Case Study on State Senior High School 4 Enrekang). Edumaspul: Jurnal Pendidikan - Vol 3 No. 2 (2019) page 22 - $30 . \quad$ DOI: https://doi.org/10.33487/edumaspul.v 3i2.133

13) Mustakim, M., \& Ismail, I. (2018). The Influence of English Camp in Improving Speaking Skill of English House Course Students in Maroangin Kabupaten Enrekang. Edumaspul: Jurnal Pendidikan, 2 (2), 61-70.

https://doi.org/10.33487/edumaspul.v $2 \mathrm{i} 2.10$

14) Mustakim, Yunus Busa, Magfira Mustafa. (2019). Japanese Non-verbal Communication by the Main Characters in the Novel of Totto-chan and the Light on Curtain of Sakura (An Analysis of Kinesics). Edumaspul: Jurnal Pendidikan.

15) Niehaus, E., \& Crain, L.K. (2013). Act local or global? Comparing student experience in domestic and international service-learning programs. Michigan Journal of
Community Service Learning. 20(1), 3140.

16) Pechak, C., \& Thompson, M. (2009). International service-learning and other international volunteer service in physical therapist education programs in the United States and Canada: An exploratory study. Journal of Physical Therapy Education, 23, 71-79.

17) Perdana, Holilulloh, Nurmalisa. (2013). Pengaruh Pelaksanaan Kuliah Kerja Nyata Terhadap Keterampilan Sosial Mahasiswa Program Studi PPKN. Jurnal Kultur Demokrasi. Vol 1, No 7.

18) Pless, N.M., Maak, T., \& Stahl, G.K. (2011). Developing responsible global leaders through international service learning programs: The Ulysses experience. Academy of Management Learning and Education, 10(2). 237260.

19) Pechak, C. M., \& Thompson, M. (2009). A Conceptual Model of Optimal International Service-Learning and Its Application to Global Health Initiatives in Rehabilitation. Physical Therapy, 89(11), 1192-1204.

20) Sandy, M., \& Holland, B. (2006). Different words and common ground: Community partner perspectives on campus-community partnerships. Michigan Journal of Community Service Learning, 13, 30-43.

21) Tryon, E. A. (2008). The ungeard voice: Community organisations and service learning. Philadelphia, PA: Temple University Press. https://doi.org/10.2522/ptj.20080378

22) White, N. (2001). Kaplan Writing Power. New York: Simon and Schuster. 